\title{
Empires' city-building and the 1792 intervention of Aupaumut's book
}

\author{
Barbara Eckstein ${ }^{\star \dagger}$ (D) \\ 308 EPB, University of Iowa, Iowa City, IA 52242, USA \\ ${ }^{\star}$ Corresponding author. Email: barbara-eckstein@uiowa.edu
}

\begin{abstract}
Following indigenous thought, this article urges readers to understand that the past lies before us, more knowable than our ideologies ordinarily allow. The article specifically asserts that if, for England, imperialism was the last model of city-building, in the United States it was the first. A pattern of 'improvement' financed by negative externalities established from first contact remains visible, especially in US metropolitan areas. The article's example is one site in Ohio. Indicative of virtually all US metropolitan areas, it has nonetheless a specific history that includes an occasion, recorded in negotiator Hendrick Aupaumut's 1792 narrative, when a break from the pattern was possible.
\end{abstract}

As I look at the town now, dwindling without grace, I think how strange that lives were lost in its formation.

Louise Erdrich, The Plague of Doves

\section{Imperialism and improvement: first principles of city-building}

A school bus is unexpected on a congested highway lined with commercial and retail businesses. But it appeared: square, dirty and yellow, lumbering along. If its presence was unexpected, its stopping to release children in this territory was even more unlikely. But it crawled to a stop in front of a brick bungalow, one of a handful, each in isolation along miles of this commercial strip. The bus waited, and eventually a small child emerged, jumping from the last high step to the pavement. As slowly as the bus had pulled to a stop, just that quickly the child darted up the driveway and disappeared into the house. Maybe the child was glad to be home and likely warned by parent or bus driver to run like the dickens into the house and away from the traffic surging ahead of the speed limit. What with the isolation of the residence and of the child, the dash up the drive looked, nonetheless, like a

\footnotetext{
${ }^{\dagger}$ I am grateful to my colleagues Phil Round and Stephen Warren for their good work and generous advice.

(C) The Author(s), 2021. Published by Cambridge University Press. This is an Open Access article, distributed under the terms of the Creative Commons Attribution licence (https://creativecommons.org/licenses/by/4.0/), which permits unrestricted re-use, distribution, and reproduction in any medium, provided the original work is properly cited.
} 
retreat at the advancing edge of a new world order, someone's idea of improvement. The edge of removal.

This article argues that the ideas of improvement evident in the twenty-firstcentury US metropolitan area described above - aggressive displacement and erasure of established neighbourhoods and people as well as of diverse ecologies and externalizing the costs of this restive land use onto these individuals and places were the ideas of improvement that defined city-building from early contact between indigenous people and European immigrants prior to and coterminous with the founding of the republic when multiple empires vied for control of the land. The article takes its example from Ohio Country. But this particular edge of removal where the retreating child disappears into the isolated bungalow, at the intersection of Jackson Township and the Canton city limits in Stark County in north-eastern Ohio, could have been a lot of places in the metropolitan areas of the United States. Any of them would provide a person the opportunity to sit in traffic amidst acres of parking lots and scores of franchise restaurants and ask, while a few indistinguishable birds circle high above, how did we get here?

A story of a deindustrialized Rust Belt city would be one answer. A story of segregated development would be another. Urbanists could distance themselves from this place, proclaiming it suburban and not part of their vision for dense, green, creative, humanly diverse cities. But all of these important stories unfold, it turns out, across metropolitan areas. This is made clear, for example, by Colin Gordon's analysis of the systematic, land-based oppression of African Americans in the St Louis area with its proliferation of separately constituted municipalities. ${ }^{1}$ To make sense of stories and cities, US cities anyway, we should first acknowledge the familiar metropolitan areas they occupy.

Decades ago, in The Country and the City, Raymond Williams demonstrated that attitudes about the country persist and shape attitudes toward the city well after a society is predominantly urban, as evidenced, he said, in the history of English literature. ${ }^{2}$ The same logic applies to attitudes about the city that persist in multiple narrative forms well after most cities, in the USA anyway, have devolved into metropolitan areas with diffuse and differently advantaged populations and, at best, uneven evidence of planning for sustainability. Williams moves toward an argument that pulls 'metropolitan' and 'imperial' into the same conversation and the same space:

in current descriptions of the world, the major industrial societies are often described as 'metropolitan'... What is meant is an extension to the whole world of that division of functions which in the nineteenth century was a division of functions within a single state... What was happening in the 'city', the 'metropolitan' economy, determined and was determined by what was made to happen in the 'country'; first the local hinterland and then the vast regions beyond it, in other people's lands... Thus one of the last models of 'city and country' is the system we now know as imperialism. [Whether economic, monetary, commercial controls or political, cultural, and military

\footnotetext{
${ }^{1}$ C. Gordon, Mapping Decline: St. Louis and the Fate of the American City (Philadelphia, 2008).

${ }^{2} \mathrm{R}$. Williams, The Country and the City (New York, 1982), 2.
} 
intervention], the dominant relationships are still, in this sense, of a city and a country, at the point of maximum exploitation [by imperialism]...What is offered as an idea, to hide this exploitation, is a modern version of the old idea of 'improvement'.

Canton and Jackson Township's twentieth-century and twenty-first-century stories deserve scrutiny, but this article rewinds the clock further on this territory of human and other inhabitants prior to and through their contact with Europeans for whom imperialism and colonialism were not the last model of city and country but the first. This past lies before us. A generation ago, when Andres Duany, Elizabeth Plater-Zyberk and Jeff Speck assumed, in Suburban Nation, that 'you' were stuck in traffic amidst 'a national landscape...largely devoid of places worth caring about', the solution they offered 'you' was New Urbanism, a redesigned future city. ${ }^{4}$ Though the subsequent influence of New Urbanist ideas has been substantial in US cities coast to coast, the effects of imperialist first principles remain little addressed and thus more evident than ever.

It is important to track not only those imperialist first principles but also credible, countervailing attempts to divert the seemingly inevitable practices and narratives of imperialism. Although the current form of economic development in the metropolitan area of Canton could be many places in the USA, the history and ecology of this place is particular. In these particular events in the particular places of Ohio Country, the prospects for intervention in violent imperial desires and inequitable practices of improvement were also particular. Imperial desires were often enacted and are often remembered with a sense of inevitability that warrants comparison to what urban planners call path dependency, that is, a following of the same practices, often of economic development, because the infrastructure, physical and bureaucratic, enabling the following of that path has already been well established. Alternatives seem unfeasible. Well-worn paths can be made to seem rational when they are not.

The paths and goals of empire are neither inevitable nor rational. The word 'empire', as it applies in the eighteenth century (and earlier) not only to the inchoate United States but also to the British, French and Iroquois, describes land-based material ambitions however incoherent especially when paired with more highminded political ideals. Amy Kaplan's definition of US imperialism in the later nineteenth and twentieth centuries is apt for the empires in eighteenth-century Ohio Country as well: 'a network of power relations that changes over space and time and is riddled with instability, ambiguity, and disorder.' ${ }^{5}$

\section{The construction of feeling for the inevitability of empire}

The middle of the foundational story of the Canton metropolitan area emphasizes the construction of naive amazement as the feeling to accompany, by obscuring, acts of imperial violence. So I begin there. In the first week of September 1837,

\footnotetext{
${ }^{3}$ Ibid., 279, 283-4.

${ }^{4}$ A. Duany, E. Plater-Zyberk and J. Speck, Suburban Nation: The Rise of Sprawl and the Decline of the American Dream (New York, 2000), ix-x.

${ }^{5}$ A. Kaplan, The Anarchy of Empire in the Making of U.S. Culture (Cambridge, MA, 2002), 13-14.
} 
174 Ottawa (Odawa) travelled through the Stark County territory on flatboats moving down the recently completed Ohio Canal that followed the bank of the Cuyahoga, then Tuscarawas and Muskingum Rivers. The Ottawa had delayed a decision on their removal until after the end of the Jackson presidency. But his replacement, Martin Van Buren, retained Jackson's commitment to the emigration of Indians from the eastern United States, north and south - 'emigration' being the word preferred by Jackson for the forced removal of the tribes. The Ottawa travellers moving through Stark County were emigrating from their former reserved lands in the Maumee Valley, now north-west Ohio. Having come by steamer, via Lake Erie, from the port at the mouth of the Maumee, to the port of Cleveland, they were headed, via the canal, to Portsmouth and then, by steamboat on the Ohio and Mississippi Rivers, to Cincinnati, then St Louis and finally to the Osage River Agency that would locate them in north-east Kansas. Of the travellers, 80 per cent were under 25, and 30 per cent of these were under 10. Men outnumbered women 2:1. Four people were lost during the journey. ${ }^{6}$

Not all Ottawa in the Maumee Valley chose to go to Kansas. Some, especially elders, removed to Ottawa territory in Canada, though the cold winter of 1838 made that choice a brutal one. Some chose to stay in Ohio even without any territory of their own. The federal government, through its Van Buren appointee, Thomas Hartley Crawford, prepared a second journey for what they considered the last of the Ottawa in the Maumee Valley. In the spring of 1839 when the date of departure was near, 40 or 50 of those on the manifest were missing; 30 had gone east, most of these women and children. Maumee trader Robert Forsyth, agent in charge of the planned 1839 journey, wrote Crawford that he could only stand and watch as the Navarres loaded the women and children into canoes and headed farther east, where they would never be found'. ${ }^{7}$ Perhaps these women had a premonition of bleeding Kansas - the antebellum violence in that territory between slaveholders and abolitionists as Kansas approached statehood - and knew well Anglo-American willingness to enslave Indians. In any case, on 25 July 1839, the supposed final removal of Ottawa from Ohio occurred. The Commodore Perry carrying 108 Ottawa left 'the dock [at the mouth of the Maumee] to the cheers of hundreds of onlookers' ${ }^{8}$

If the 108 Ottawa left the Maumee Valley in sorrow, according to Forsyth they soon found sights to amaze them along the Ohio Canal: 'centers of trade and manufacturing, and the countryside filled with neatly ordered farms and dairies'.' Along the way, including from Akron to Massillon through the current metropolitan area of my concern, 'people came out to meet the Ottawa. Most had never seen Indians before and', in Forsyth's judgement, 'treated them kindly'. ${ }^{10}$ The Ottawas' amazement may well have been at such a swift and thorough transferral of land that they knew differently hardly a generation ago. Our amazement might dwell not on the cheering usurpers of Indian lands in the Maumee Valley but on their fellow Ohioans, the new residents of Stark County, who are, at least according to

\footnotetext{
${ }^{6} \mathrm{M}$. Stockwell, The Other Trail of Tears: The Removal of the Ohio Indians (Yardley, PA, 2014), 270-1.

${ }^{7}$ Ibid., 274-5.

${ }^{8}$ Ibid., 275.

${ }^{9}$ Ibid., 275.

${ }^{10}$ Ibid., 275.
} 
Forsyth, naïve innocents unaware of the violent past passing before their eyes. Rather than succumb to stupefaction and swallow the hallucinogen of naïve kindness, this article proposes we start at the beginning of the past that lies before us, looking for what is knowable rather than presupposing what is inevitable.

\section{Millennia of indigeneity and centuries of colonialism in, out of and back to north-eastern Ohio}

Stark County sits on the backbone of Ohio Country, an east-west ridge dividing rivers flowing north to Lake Erie from rivers flowing south to the Ohio River. Though its boundaries lie beyond the confluence of the large Allegheny and Ohio Rivers that drew successful Indian settlements in the Middle Ohio River Valley for millennia, Stark County too contains some evidence of early residents. At a site called Nobles Pond, one of several small lakes and ponds in Jackson Township just to the west of the retreating child of the twenty-first century with whom this article began, volunteers and researchers have found thousands of pieces of stone scrapers and many fluted arrowheads. The evidence suggests this site was occupied some 11,000 years ago by hunters. ${ }^{11}$ Although archaeologist David $S$. Brose concludes that 'there may in fact have been very little late prehistoric occupation of that [backbone] region of short growing seasons, ${ }^{12}$ it can be called the beginning of the human story in Jackson Township nonetheless.

Although a bright line cannot be drawn from Nobles Pond across millennia to the south shore of Lake Erie in the sixteenth century, historians believe the Erie and other Iroquoian speakers there, such as the Haudenosaunee and Neutrals, traded for some time with the successful Fort Ancient people further south, until, in 1654 and 1656, warring Iroquois drove the Erie and the Neutral out and into a colonial world exploiting enslaved labourers, Indians among them.

Those Erie and Neutrals who survived the Iroquois wars are thought to have briefly coalesced with Fort Ancient villagers before moving farther to the south, first to the falls of the James River, where they slaved on behalf of the Virginians, and then onto the fall line of the Savannah River, where they slaved for the Charles Town traders - [Virginians and Charles Town traders both being immigrants from Europe]. These heavily armed survivors of the Iroquois wars traded Indian captives for English guns in order to survive,

writes historian of the Shawnee, Stephen Warren. While Brose rejects the idea that the Erie came from north-east Ohio, other scholars contend that in their new role in the tobacco economy of Virginia, they were known as the Westo. ${ }^{13}$ In either case, the stories of the Westo are reminders that the property in dispute in colonial America was not only the land but Indian bodies capturable as slave labour.

\footnotetext{
${ }^{11}$ R.M Gramly and G.L. Summers, 'Nobles Pond: a fluted point site in northeastern Ohio', Midcontinental Journal of Archaeology, 11 (1986), 97-123.

${ }^{12}$ D.S. Brose, 'Penumbral protohistory on Lake Erie's south shore', in D.S. Brose, C.W. Cowan and R.C. Mainfort Jr (eds.), Societies in Eclipse: Archaeology of the Eastern Woodlands Indians, AD 1400-1700 (Washington, DC, 2001), 65 n. 1.

${ }^{13}$ S. Warren, The Worlds the Shawnees Made (Chapel Hill, 2014), 48, 50, 85, 242 n. 52, citing Brose.
} 
Through the subsequent colonial wars that determined the occupants of Ohio Country, including current Stark County, and the guerilla warfare and terrorism following each, the Indians most established along the Tuscarawas River were the Delaware. Unlike the Erie or the Shawnee, the Delaware (Lenape, Lenni Lenape) did not have deep roots in Ohio Country. Rather they were moving away from the economic claims and threats of empire: British, Iroquoian, French and American. By the eighteenth century, they had left their villages in the Delaware Valley on the eastern seaboard where they and the river acquired a new name from colonial settlers. They first took refuge in the colony of Quaker William Penn who spoke of peacefully melding Indian and English in Pennsylvania. ${ }^{14}$ Even if this claim was not long or widely upheld, it was an improvement on territories such as Virginia where the House of Burgesses passed laws legalizing the sale of Indian people attempting to travel through and out of the state. 'All along the Atlantic colonies, Native people shared stories of captivity and enslavement. When whole villages relocated, they developed an acute understanding of the differences between colonies.' That said, in Pennsylvania, Indians were also sometimes enslaved and always subject to traders in alcohol who often devastated their villages and drove them into debt. ${ }^{15}$

Pennsylvania's failure to control unscrupulous traders, and the opportunity to move beyond empire, prompted some Shawnee and others, like some Delaware, to leave Pennsylvania in the 1720s for the Middle Ohio River Valley, the former territory of Fort Ancient. Because the Iroquois signed away Delaware lands to Europeans in 1737 and 1744, claiming to possess them by right of conquest, more Delaware had increasing reasons to move into Ohio. The movement of non-Iroquoian Indians out of Pennsylvania incited non-Indians' worry that they were aligning themselves with the French, though in fact self-imposed migrations into, or back into, Ohio Country made it difficult for any of the competing empires to know the allegiances of these people. Stephen Warren argues that the Shawnee and their Indian confederates in the Ohio River Valley wanted to 'mediate the traffic between empires' - French, British and Iroquoian. During the Seven Years War (1754-61), a series of treaties using dubious claims about Iroquois conquests continued to divest the Delaware and others of their land in Pennsylvania. ${ }^{16}$

The earliest Delaware emigrants to Ohio Country did not settle in the Tuscarawas Valley of current Stark County, but the later Delaware emigrants did. In the eighteenth century, despite invasions and claims by the Iroquois nations, and despite population decline, the Wyandot (Huron) had enough hold on eastern Ohio Country to host the displaced Delaware on the Tuscarawas, above its confluence with the Muskingum, at the outset of the Seven Years War in 1754. These Delaware moved to Ohio Country with the Wyandot assurance that they would not sell to whites the land proffered to the Delaware along the Tuscarawas River

\footnotetext{
${ }^{14}$ C.A. Weslager, The Delaware Indian Westward Migration: With the Texts of Two Manuscripts (18211822) Responding to General Lewis Cass's Inquiries about Lenape Culture and Language (Wallington, PA, 1978), 8-9.

${ }^{15}$ Warren, Worlds the Shawnees Made, 166, 169.

${ }^{16}$ Ibid., 171, 177, 192, 225.
} 
as the Six Nations, i.e. the Iroquois, had done in the Susquehanna Valley in Pennsylvania. ${ }^{17}$

The territory provided them was partially navigable by canoe and included trails linking them to the Cuyahoga, Sandusky and Huron Rivers,

an important commercial avenue for Indian tribes...The bottom lands along the Tuscarawas were fertile and yielded abundant corn crops, and on both sides of the river there were virgin forests occupied by deer and other wild animals...At this time, with the exception of a few scattered families (mostly traders with Indian wives), there were no white settlements in the Ohio Territory. ${ }^{18}$

The Delaware in Ohio Country were nonetheless in a new, or rather, another, middle ground, a heterogeneous site of Indian Country. Richard White concludes that this middle ground, in the Ohio Valley, was defined by access to European goods, such as arms and alcohol, that led to unruly behaviour of young Indian men in defiance of village elders. ${ }^{19}$ It is true that before entering Ohio Country the Delaware had already adopted the use of firearms that they themselves lacked the iron skills to repair. For this and other reasons, they shot more and more animals to trade for European goods and particular European skills. But other complications were also afoot. For example, Moravians pressured them to embrace their Christianity, creating tensions between some settlements of Delaware and others. On the Tuscarawas, the Moravians founded, in 1772, two towns for Christian Delaware: Schönbrunn and Gnadenhütten.

Themselves not a united people, the Delaware would continue to be subject to the pressures from different groups of Indians and non-Indians to take up their causes at the risk of their own prospects for peace and prosperity on the Tuscarawas River. Though in 1758 the Moravian Christian Frederick Post negotiated an agreement that there would be no white settlers west of the Allegheny Mountains and in 1759 British Indian agent George Croghan promised the Delaware that once the French were routed, the British would retire from the lands west of the Alleghenies, that is, Ohio Country, at the end of the Seven Years War in 1761, these promises were not kept. ${ }^{20}$

\section{Colonial manipulation of Indian lands and imperial laws: externalized costs and racist narrative}

Legal historian Stuart Banner distinguishes between property and sovereignty in addressing the two overlapping stories of how the Indians lost their land and the law that was supposed to determine how the Indians lost their land. ${ }^{21}$ We think we know this story, but the story of this past that lies before us warrants retelling

\footnotetext{
${ }^{17}$ Weslager, Delaware Indian Westward Migration, 24, 8-9, 17.

${ }^{18}$ Ibid., 24, 26.

${ }^{19} \mathrm{R}$. White, The Middle Ground: Indians, Empires, and Republics in the Great Lakes Region, 1650-1815 (New York, 1991), 186-222.

${ }^{20}$ Weslager, Delaware Indian Westward Migration, 29-36.

${ }^{21}$ S. Banner, How the Indians Lost Their Land and Power on the Frontier (Cambridge, MA, 2005), 3, 7, 5.
} 
and retelling again until it is written on the landscape. So-called right of discovery was used by Europeans to claim sovereignty over Indian lands, but that Indians had property rights was largely agreed upon by the early seventeenth century. ${ }^{22}$ In short, at least before the American Revolution, most Indian land acquired by non-Indians was bought. Because land in North America was cheap, especially relative to England, and because colonists who had bought land did not brook arguments that Indians had never owned it to begin with thus undermining their purchases, the British colonists and their imperial government were interested to maintain a legal process of purchasing Indian lands from them. ${ }^{23}$ It is important to note here that when John Locke was arguing that Indians had no property rights because they did not engage in agriculture, he was out of step with the times. When Locke was writing, everyone, claims Banner, knew that Indians were farmers and had a system of property. In the late seventeenth century and into the eighteenth, Locke's argument was not influential. British subjects went right on buying land from Indians. ${ }^{24}$ That these Indian farmers were principally women may have something to do with the cognitive dissonance that sporadically and persistently arises on this point.

Insisting that the degree of volition in these transactions was on a continuum, Banner argues that land sales were 'not [beneficial] to Indians collectively, but it was in the interest of individual tribes' ${ }^{25}$ Nevertheless, the reasons for increasing Indian poverty were many: Anglo-Americans oversettled land and thus created ecological damage through such practices as overhunting and mill dams; ${ }^{26}$ Indians relied on land as their only or principal form of wealth and so it was the only way to pay off accumulated debt held by European traders; settlers occupied land illegally and, though the imperial centre or colonial government might legally side with the Indians, they were too weak and far away and too dependent upon frontier colonists to stop them; Indians may have initially understood transactions as building alliances and not forfeiting their rights to use of lands traditionally within their purview; and, finally, ambiguity about who had the right to sell land in societies where lands had been held in common opened many doors to fraud that local colonial authorities could easily promote and exploit. Also, as both regulator and participant in the land market, the colonial government 'had the power to exclude competing purchasers'. Still, Banner argues, the English found it distasteful to think of themselves as conquerors. ${ }^{27}$

The inability or unwillingness of imperial and colonial governments to uphold their own laws governing the acquisition of Indians' property was a central feature of the imperial chaos later constructed as inevitable white supremacy. The contracts for purchasing property were so out of control by the 1750s that proposals were launched to prohibit private sales (behind closed doors), to allow sales only to

\footnotetext{
${ }^{22}$ Ibid., 15.

${ }^{23}$ Ibid., 21, 26, 28.

${ }^{24}$ Ibid., 47.

${ }^{25}$ Ibid., 52.

${ }^{26}$ C. Merchant, Ecologcial Revolutions: Nature, Gender, and Science in New England, 2nd edn (Chapel Hill, 2010), xiii. Merchant speaks of these activities as the two ecological revolutions: colonial and then capitalist.

${ }^{27}$ Banner, How the Indians Lost Their Land, 73, 84.
} 
the crown and not to individuals, and to set a boundary beyond which land sales would be prohibited completely. Though nothing was done during the Seven Years War, years of mayhem that only exacerbated land grabbing, fraud and violence, the Proclamation of 1763 replaced the practice of contracts for land sales with the practice of treaties for land acquisition. But a line drawn in England in ignorance northsouth down the Appalachian Mountains was hard to interpret among multiple tribes, and settlers swarmed across the boundary. Subsequent treaties were signed, but the important point is not only that the imperial and colonial governments did not or could not enforce their boundaries or their treaties, but also that their relationship with illegal settlers encouraged them. Because the only real deterrent to illegal settlement was Indian resistance, the colonial governments subsidized the settlers' illegal actions whenever they sent in the military to fight the Indians. Non-Indian settlers externalized the cost of their illegal actions and got away with it. ${ }^{28}$ Settlers, or the land speculators encouraging their aggressive incursions into Indian lands, are the agents establishing a practice that demands the imperial government break its own laws and use its resources to defend illegal actions. The spoken or unspoken justification for this demand is cultural (increasingly racial) solidarity. The motive is economic - whether desperation on the part of some settlers or just greed on the part of speculators. This is not to say the government was not responsible for its own actions. It is to observe to what extent the government is the tail being wagged by the dog of land speculators and settlers.

While the imperial government in London was drawing a line down the ridge of Appalachia and George Washington was declaring land acquisition good business nonetheless, the Delaware in Pennsylvania and Ohio Country were both attempting peace settlements and meeting violence with violence. In Pennsylvania, Delaware leader Teedyuscung tried repeatedly to save his people's home valley in a place called Wyoming through negotiations with colonial authorities and their partners in the Chain Covenant, the Six Nations, i.e. the Iroquois. Though he discussed moving to Ohio, before he could do so, he was murdered in his home in April of 1763, and Wyoming was burned to the ground. Survivors fled, some to Moravian missions.

About two weeks later, ten or twelve families from New England were comfortably planting themselves down at Wyoming, and a great many more were expected daily. They found the valley conveniently deserted...Later in the month 150 more Connecticut settlers arrived, most of...[whom] had been chased away the preceding fall by Tom King and Teedyuscung. ${ }^{29}$

Biographer of Teedyuscung Anthony Wallace argues that the raid on Teedyuscung and his people at Wyoming was conducted by the Susquehanna (Land) Company of Connecticut whether through Indian hired assassins or not. In either case, the massacre prompted revenge. 'Six months after the murder, Teedyuscung's son, Captain Bull, led the Delaware war party which massacred the Connecticut settlers at Wyoming. ${ }^{30}$

\footnotetext{
${ }^{28}$ Ibid., 86-8, 91, 99.

${ }^{29}$ A. Wallace, King of the Delawares: Teedyuscung, 1700-1763 (Phildelphia, 1949), 258-9.

${ }^{30}$ Ibid., 260.
} 
The Delaware then joined Pontiac's Indian confederation resisting Anglo-American illegal settlement. But in Ohio, the Delaware were pushed back to the Tuscarawas River by Colonel Henry Bouquet's troops who forced them to release white prisoners. $^{31}$

As these violent events were unfolding in the mid-eighteenth century, the Delaware, and all indigenous peoples, were losing their national identities, which imperial and colonial Europeans once recognized, to racial stereotyping by these same people. In Bouquet's Expedition against the Ohio Indians in 1764, Bouquet's contemporary Pennsylvanian William Smith notably uses the word 'savages' to describe all Indians, a 'seismic shift in attitudes towards Natives that took place in the 1750s and early 1760s', claims historian Michael McConnell. ${ }^{32}$ Writing of early America after the collapse, especially in Ohio Country, of what Daniel Richter sees as a begrudging co-existence between 1720 and 1750, he summarizes, "Whites and Indians had to learn...that there were such clear-cut "racial" categories as "white" and "Indian" before "westward expansion" across a steadily advancing "frontier" could become the trajectory for a nation that was itself a belated result of the same learning process. ${ }^{33}$ The idea that Indian peoples themselves were in need of improvement through the cruelty and kindness of whites settled like acid rain over the continent and its poison sunk deep into the earth.

Indians' resistance to illegal settlers' claims on their land, increasingly constructed as savagery, provides further excuse, a racial excuse, for Anglo-American military intervention in support of white settlers. Those white settlers' violence was reimagined as the steady hand of improvement while the lawlessness of empire provoked chaos. During the American Revolution, the Delaware in Ohio Country were divided in their loyalties and succumbed to intrigue and in-fighting. The Delaware leader Captain Pipe argued for fighting alongside the British; White Eyes, who had US allies, argued for remaining neutral. The Christian Delaware tried to remain neutral even as the Moravian missionaries funnelled information to the Americans. In 1782, with the Delaware loyalties divided, Moravians told the Americans at Fort Pitt (Pittsburgh) that Pipe intended an assault. Violence followed. The US-allied Delaware Killbuck leading others of his community attacked Delawares at Coshocton. Pipe and some Wyandots' attack on settlers precipitated the Pennsylvania militia's indiscriminate, brutal killing of innocent, Christian Delaware at Gnadenhütten, 96 in residence, including children. ${ }^{34}$

Following the Treaty of Paris at the end of the American Revolutionary War, the niceties of legal argument and ambiguous rhetoric about conquest were gone temporarily. In 1783, US General Philip Schuyler told the Six Nations, "'We are now masters and can dispose of the lands as we think proper or most convenient to ourselves."'35 On the one hand, through the 1780s, the new US government annexed considerable land by treaty - treaties through which Indians were allotted

\footnotetext{
${ }^{31}$ Weslager, Delaware Indian Westward Migration, 36.

${ }^{32}$ W. Smith, Bouquet's Expedition against the Ohio Indians in 1764, ed., intro. and annotations by M. West, foreword by M.N. McConnell (Kent, OH, 2017), xxi.

${ }^{33}$ D.K. Richter, Facing East from Indian Country: A Native History of Early America (Cambridge, MA, 2001), 184-5, 151, 2.

${ }^{34}$ Weslager, Delaware Indian Westward Migration, 40-1, 44-5.

${ }^{35}$ Banner, How the Indians Lost Their Land, 112, 113.
} 
reserves; on the other hand, land speculators wanted to maintain the premise that Indians owned the land and therefore it was purchasable, cheaply, through practices such as acquiring it in exchange for Indians' debt and in agreements with Indians other than those with rightful claim on the land. When in the midst of yet more voracious settlement and violent resistance, the Continental Congress did try to enforce a policy much like the Proclamation of 1763 , they were no more successful than the British. Washington complained in 1784, "Such is the rage for speculating in, and forestalling of lands on the No. West side of the Ohio that scarce a valuable spot within any tolerable distance of it, is left without a claimant." ${ }^{36}$ Settlers knew that provoking conflict with Indians was the best way to get the government to acquire the land by treaty. And the best way to sell the settlers' story about inevitable violence was to promote the racial stereotype of Indian savagery.

\section{Confederated Indian resistance and the stronghold of western Ohio Country}

Indians' response was again to form a confederacy across Indian nations and to ground their polity in the established Indian settlements of north-west Ohio Country. The USA was not their master. The Delaware, like the Wyandot and other Indians, who were allotted reserves in Ohio Country further north and west found the prosperous, established settlements of Miamis, Weas and Ouiatenon on the Wabash, White, Sandusky, Miami and Maumee Rivers in western Ohio Country hospitable. Many Delaware moved to the White River though 150 Christian Delaware did follow missionary David Ziesberger to Canada. ${ }^{37}$ The confederated Indians of western Ohio Country resisted any treaty that diminished Indians' lands west of the Ohio River. Most notable, confederated Indians defeated US troops under General Josiah Harmar in 1790 and General and Territorial Governor Arthur St Clair in 1791 in western Ohio Country.

US Secretary of War Henry Knox may have argued that buying Indian lands was cheaper than war, but the Washington administration used violence when 'commerce' did not work. ${ }^{38}$ In 1791, George Washington sent a message to Henry Knox ordering the Kentucky militia under General Charles C. Scott - a man Washington knew to be unscrupulous - "'to proceed to the Wea or Ouiatenon towns of Indians, there to assault the said towns, and the Indians therein either by surprise, or otherwise, as the nature of the circumstances may admit sparing all who may cease to resist, and capturing as many as possible, particularly women and children"'. ${ }^{39}$ Scott's men laid waste to the villages, the vast cornfields, vegetable gardens, apple orchards, houses and people. From two separate major villages, they captured 100 women and children and incarcerated them in two forts on the Ohio River. Susan Sleeper-Smith argues that Washington targeted these villages because he knew them to be the extensive bread basket of the confederated Indian movement that had defeated the US military twice in north-west Ohio; he knew women to be at the heart of their agricultural and trading success; he wanted the

\footnotetext{
${ }^{36}$ Ibid., 125, 126.

${ }^{37}$ Weslager, Delaware Indian Westward Migration, 48.

${ }^{38}$ Banner, How the Indians Lost Their Land, 130, 131.

${ }^{39}$ S. Sleeper-Smith, Indigenous Prosperity and American Conquest: Indian Women of the Ohio River Valley, 1690-1792 (Chapel Hill, 2018), 1.
} 
extensive, already cultivated farmlands for US farmers; he wanted to profit from his own land speculations; and he wanted the sale of western lands to reduce the war debts of the new nation. ${ }^{40}$ In fact, since as early as the seventeenth century, the agricultural and trading success of the Indians in the middle and western Ohio River Valley had been known by imperial and colonial Europeans. Miamitown was the largest and most important village in the Ohio River Valley, growing as it welcomed other Indians migrating into the region. ${ }^{41}$

Writing of New England in previous centuries, William Cronon asserts not only that 'one must not exaggerate the difference between English and Indian agricultures', but also that a pattern emerged beginning at Plymouth itself of 'New England towns ma[king] their first settlements on the sites of destroyed Indian villages'. Because virgin soil epidemics killed as much as 95 per cent of an Indian village population in New England, the collapse and subsequent usurpation of these villages, especially those desirable settlements with cornfields, was easy for settlers. ${ }^{42}$ This process of usurpation whether for settlement and cultivation or acquisition of capital from land ownership was well established when Teedyuscung and his people lost Wyoming in Pennsylvania, but by then the transition was the result of outright murder rather than the infestation of new microbes.

In western Ohio Country, Miami and Wea society presented a new challenge to this expected pattern of white improvement which is to say ethnic cleansing as an externalized cost of land speculation and settlement by whites. The Miami women had long since developed an extensive agricultural enterprise and mastered the international trade in furs to acquire prosperity for their people and villages. Their food production was not 'mere horticultural' as the labour of indigenous women further east has been understood even when those women's efforts were supplying 85 per cent of the calories for their villages. ${ }^{43}$ Also unlike the Indians further east, these western Ohio villages had reasons to be less susceptible to European diseases and knew how to isolate themselves. ${ }^{44}$ And they had a massive swamp in which their men could hunt with greater protection from European incursion. ${ }^{45}$ The multiple tributaries to the Wabash and Ohio enabled a system of communication and transportation that had not been mapped by Europeans in the age of exploration. For the Miami, the riverine landscape was their habitat and the site of their origins. ${ }^{46}$ By the 1780 s, with their trade networks, agricultural enterprise and political and military confederation of multiple Indian peoples to whom they had offered hospitality, the Miamis and their Indian allies had reason to resist aggression from the inchoate USA.

In 1788, three years prior to Washington's order to unleash General Scott and the Kentucky militia on the established settlements of the western Ohio River

\footnotetext{
${ }^{40}$ Ibid., 4-5.

${ }^{41}$ Ibid., 137, 146.

${ }^{42} \mathrm{~W}$. Cronon, Changes in the Land: Indians, Colonists, and the Ecology of New England (New York, 1983), 127, 40, 87.

${ }^{43}$ Merchant, Ecological Revolutions, xvii.

${ }^{44}$ Sleeper-Smith, Indigenous Prosperity and American Conquest, 124-6.

${ }^{45} \mathrm{D}$. Bogart, “My great terror, the black swamp": northwest Ohio's environmental borderland', Miami University, Oxford, Ohio, MA thesis, 2015.

${ }^{46}$ Sleeper-Smith, Indigenous Prosperity and American Conquest, 120-1.
} 
Valley, when the USA wanted to strike a deal with the Ohio Indians, the Miami refused to attend the meeting, scoffing at the idea that the Americans wanted peace. ${ }^{47}$ In 1793, after General Scott's scorched-earth attack, when the USA again called Indians together to coerce the sale of Indian lands in Ohio Country, Indians had reason to rename Washington 'the Town Destroyer'. ${ }^{48}$ US commissioners, having decided with land speculators, after all, that the property rights still belonged to the Indians, wanted a meeting in order to deliver what they thought would be good news to the Indians: now the USA had the right of purchase. Neither naïve nor amazed, the Indians responded, "You want to make this act of common justice a great part of your concessions and seem to expect that, because you have at least acknowledged our independence, we should, for such a favor, surrender to you our country."

The 1790s in Ohio Country saw extraordinary efforts, through negotiations and through war, to reach an agreement about land ownership and thus relation of country and city or village within those lands. But the temptations of empire and the patterns of white improvement hung over all activities, peaceful and not. Following the 1790s Indian victories over the US Army and the subsequent 1791 attack on prosperous Wea and Ouiatenon towns by the Kentucky milita and prior to the 1793 refusal of western Indians to meet with US commissioners, Indians held two important conferences in the diverse Wabash and Maumee River Basins, one at Vincennes and the other at The Glaize above the principal settlement Miamitown. At Vincennes, women and children outnumbered men among participants - in part because Americans were returning prisoners taken the previous year - and the women spoke publicly for peace and settlement of Indian claims for lands north of the Ohio River. In this last decade of the eighteenth century, in this place, these women entered the fray of governance, the domain of men in indigenous communities of New England. ${ }^{50}$ Meanwhile, the Miami and Shawnee issued invitations to The Glaize, a conference attended principally by male warriors and sachems, to villages across the Ohio Valley, Great Lakes and into the south-east and invited the USA to send an Indian representative. $^{51}$

\section{An emissary for peace records Indian interrogation of imperial principles}

Captain Hendrick Aupaumut, a Mahican sachem committed by culture to the practice of negotiation and a US veteran of the American Revolution, volunteered to go to the meeting at The Glaize on behalf of the USA. Officials in Washington had sought out Mohawk Joseph Brant and the Seneca leaders Red Jacket and Cornplanter as possible emissaries to the western Indians even though these Iroquoian leaders and their people had fought with the British in the recent American Revolution and were frequent combatants with the western Indians as

\footnotetext{
${ }^{47}$ Ibid., 227.

${ }^{48}$ Banner, How the Indians Lost Their Land, 140.

${ }^{49}$ Ibid., 139.

${ }^{50}$ Merchant, Ecological Revolutions, xvii.

${ }^{51}$ Sleeper-Smith, Indigenous Prosperity and American Conquest, 296, 303. See Sleeper-Smith for description of the important Vincennes meeting at which women's voices dominated.
} 
well. 'Like their British predecessors', writes Alan Taylor in Ethnohistory, 'American officials had an exaggerated notion of the power of the Iroquois to sway the western peoples. ${ }^{52}$ The three Iroquoian leaders turned down the offer to represent the USA in a meeting, declaring themselves the best cross-cultural negotiators, nonetheless. Taylor describes Brant as 'working all sides'. ${ }^{53}$ Unbidden, Aupaumut volunteered for the job, persuading Timothy Pickering, the US envoy, that despite the diminished military and material power of his own eastern village, because he shared an Algonquian language with most of the western Indians and was a sophisticated orator, he would be successful. The Mahicans had for some time defined themselves as mediators between the incoming Europeans and the Indians further west. Aupaumut had been maintaining a relationship especially with the Delaware and the Miami: the first, to join with him in seeking reparations for their removal from their eastern homes and the latter, to keep open the possibility of a promised, alternative home for Aupaumut's Stockbridge band if and when they wanted to settle further west. Not a toady for the USA, Aupaumut understood that his role as cultural translator and these trips to the Maumee were in the best interest of his own people. In his offer to Pickering, Aupaumut calls himself a "sincere friend to the United States... and a true friend to the people of my own colour"', but he also makes clear in a speech to the Shawnee in 1791 that his Mahican people will join their confederated army if the frontier settlers and militia do not listen to a "just and honourable peace". ${ }^{54}$

Between 1791 and 1793, via a northern route, Aupaumut travelled west on behalf of the USA four times. In the summer of 1791 and February of 1792, the British and Iroquois detained him near Detroit, and he did not reach his destination further south. But in the summer of 1792, he did arrive at the Maumee and The Glaize to consult with the peoples of the Indian confederacy. ${ }^{55}$ The circumstances of this all-Indian negotiation and the character of Aupaumut as a US emissary are at an oblique angle to the features of the earlier go-betweens in the Pennsylvania colony that James Merrell describes. Equivocal rhetoric notwithstanding, the US goal in Ohio Country was surely to remove, by any means they chose, the successful western Indians, as it had been further east, but the Indian goal was even greater sovereignty than that Merrell describes in Pennsylvania: a 'coexistence designed to keep colonists at arm's length so that Indian peoples could remain masters of their own destiny'. ${ }^{56}$ Though the US emissary, Aupaumut, made clear that his goal was peaceful co-existence and not colonial expansion. He had seen violence destroy his own village in the east; by 1750 , Pennsylvania had become an 'abattoir', and the violence in Ohio Country caused Aupaumut great sorrow. ${ }^{57}$ As leader of his Mahican band, Aupaumut had some of the status as a negotiator that Merrell concludes Indians most valued. But Aupaumut also valued the use of a shared language with the western Indians

\footnotetext{
${ }^{52}$ A. Taylor, 'Captain Hendrick Aupaumut: the dilemma of an intercultural broker', Ethnohistory, 43 (1996), 431-57, at 435 .

${ }^{53}$ Ibid., 445.

${ }^{54}$ Ibid., 435, 442.

${ }^{55}$ Ibid., 444.

${ }^{56}$ J. Merrell, Into the Woods: Negotiators on the Pennsylvania Frontier (New York, 1999), 38.

${ }^{57}$ Ibid., 37; and Taylor, 'Captain Hendrick Aupaumut: the dilemma of an intercultural broker', 450.
} 
which had been an assumed basis of negotiation by Anglo-Americans though not by Indians. While Merrell found the go-betweens in the Pennsylvania colony difficult to trace because nobody had 'paused to jot down notes', Aupaumut, fluent not only in an Algoquian language but also in English (and literate), did just that. ${ }^{58}$

Out of his journals, Aupaumut created his book, 'narration of my... journey to the western country', as a cross-cultural Indian iconography and English text book in the year of The Glaize negotiations, and it was conventionally published as English-only text later, in 1826, by the Historical Society of Pennsylvania. ${ }^{59}$

Phillip Round describes Aupaumut's original book alongside Seneca Chainbreaker's memoir of the negotiation at The Glaize and argues that the two together, as Indian books about the 1790s, 'mark the beginning of the process of constructing an imagined mixed audience of Native and non-Native auditors in the public sphere of the early republic' ${ }^{60}$ As journal, Aupaumut's book is contemporary public discourse, historical document and literary intervention, and joins traditional pipes, wampum and performance, contracts, treaties, military interventions and illegal manoeuvres as a means to negotiate the needs and desires of the many Indians and non-Indians not only in the western Ohio Country but also in the expanding US empire. The book, as originally made, offers a detailed description and visual representation of rituals and protocols and of diverse Indian opinions about the best course of action. ${ }^{61}$ The meeting at The Glaize, Aupaumut's presence there as a US negotiator and his written record of the all-Indian statecraft stand as an important intervention - possible rupture - in the imperial desires and attendant ethnic cleansing of the USA. This diplomacy is part of the past that lies before us, relentless racialized violence notwithstanding. In 1792, it was imaginable that the United States and the confederated Indians held equal power over Ohio Country and the outcomes of its ownership and even sovereignty. ${ }^{62}$

The prospects for peace and for war, in such a moment, permeate Aupaumut's book. The book repeats a visceral ritual to enact sympathy, deflect revenge and promote communication. Whether addressing himself to the Delaware, the Shawnee or others, Aupaumut speaks of them as kin, per convention although perhaps by this

\footnotetext{
${ }^{58}$ Merrell, Into the Woods, 57-8, 55.

${ }^{59}$ The title and date assigned by the Historical Society of Pennsylvania to the manuscript, Journal of a Mission to the Western Tribes of Indians by Hendrik Aupaumut, 1791, appear to have been derived from a 15 April 1826 letter from Timothy Pickering verifying the authenticity of the manuscript. The society created a printed title page with the date for the manuscript and included in its binding the 1826 and a subsequent 24 August 1827 authenticating letter from Pickering. Aupaumut's hand-written journal and tentative title with a word scratched includes no date. Pickering remembers 1791 as the year when the 'western tribes...were carrying on a distressing war against the frontier settlements'. But Aupaumut was prevented from reaching the western tribes that year. Presumably, the journal records his extended negotiations in 1792. When Pickering was penning his remembrance of his encounters with Aupaumut regarding the negotiations and attesting, in the 1820 s, to the manuscript's authenticity, Aupaumut was still alive and in Wisconsin, to where he and his people had been removed.

${ }^{60} \mathrm{P}$. Round, Removable Type: Histories of the Book in Indian Country, 1663-1880 (Chapel Hill, 2010), 103.

${ }^{61}$ Historical Society of Pennsylvania, H. Aupaumut, 'Journal of a mission to the western tribes of Indians by Hendrick Aupaumut, 1791', 1791, https://discover.hsp.org/search/Results?lookfor=Journal\%20of\%20a\% 20Mission\%20to\%20the\%20Western\%20Tribes, last accessed 1 Jul. 2020.

${ }^{62}$ Taylor, 'Captain Hendrick Aupaumut: the dilemma of an intercultural broker', 450.
} 
time a waning convention, and repeats the negotiator's ritual Merrell names 'at the edge of the woods' ceremony, acknowledging grief but cleansing the senses for the sake of understanding:

I now put my hand on your face and wipe off your eyes, so that you may see things clear, and that to a great distant. Grandfather - ...I now stretch my hand and take away all the dust from your ears, that you may now hear. And I also put my hand and clean your throat, and take away all heavy burdens which hangs on your mind, and cast it away, that you may now understand what is good for your children, and that you may have comfort. ${ }^{63}$

In speaking of each group in turn, he reports the meaningful colour and length and number of wampum he has delivered, an established, extra-linguistic, negotiating practice.

Meanwhile, he alerts the reader to messengers from every Indian leader willing and, it seems, eager to talk with him, as they send word ahead, in some cases, asking him to wait for them. This detail turns the traditional narrative into one of action, intrigue and possibility and emphasizes the diverse Indian nations participating in the confederacy. Aupaumut also reports the late arrival of Mohawk Joseph Brant who comes to counter the influence of Aupaumut and spread information about planned US attacks on villages. When Aupaumut addresses Brant, the latter turns away, destabilizing Aupaumut's intervention.

What Aupaumut does not do is include a woman among his delegation though women were architects of the agriculture and trading success of the Miami and other western tribes along the Wabash, Maumee and Glaize. Since the Iroquois traditionally included women in their decision-making, they might have had grounds to criticize Aupaumut on this shortcoming, but even in matrilinear societies, Merrell finds women were excluded from negotiations. ${ }^{64}$ And, of course, the Anglo-Americans excluded women as negotiators. In fact, US emissary Rufus Putnam did negotiate with the western Indian women at Vincennes. Together, they proposed a peace settlement between the western tribes and the US government, but the US Senate refused to ratify the proposed treaty. ${ }^{65}$

What Aupaumut does do is provide readers detailed reports of the diverse political positions of the men present at The Glaize. For all that he wants peace between the western Indians and the Americans, he reports the mistrust and ambivalence expressed by the sachems and warriors. Most pointedly, his narrative delivers to his audiences the Shawnees' desires and the Delaware Big Cat's detailed history of abuse by the Big Knifes.

The Shawannese deliverd a speech to the Five Nations [Iroquios]. The substance of it is this. We have acquainted you of our Business with the western

\footnotetext{
${ }^{63} \mathrm{H}$. Aupaumut, A Narrative of an Embassy to the Western Indians, from the Original Manuscript of Henrick Aupaumut with Prefatory Remarks by Dr. B.H. Coates (Philadelphia, 1826), 88; Merrell, Into the Woods, 20, 22.

${ }^{64}$ Taylor, 'Captain Hendrick Aupaumut: the dilemma of an intercultural broker', 446; Merrell, Into the Woods, 68, 70 .

${ }^{65}$ Sleeper-Smith, Indigenous Prosperity and American Conquest, 294-302.
} 
nations. Now you may return home, and tell your white people all what you have heard. And be it known to you that we could not speak to the Big knifes at the forts for in those places is blood. The United States have laid these troubles, and they can remove these troubles. And if they take away all their forts and move back to the ancient line, then we will believe that they mean to have peace, and that Washington is a great man - then we may meet the U.S. at Sandusky, or kausaumuhtuk, next spring. ${ }^{66}$

In reporting the differing views of the peoples present and the differing perceived political positions of the Indian confederacy and the Iroquois for whom the Anglo-Americans are 'your white people', Aupaumut conveys the deliberate ambiguity around this term Big Knifes. In 'Prefatory Remarks' to the English-only 1826 publication, Dr B.H. Coates claims he is confused about who exactly Aupaumut and the Indians at The Glaize mean when using this term. On the one hand, the Big Knifes are surely those illegal white settlers and militia with whom the Indians have exchanged revenge killings for some time. On the other hand, whether or not the Big Knifes are also the US military as directed by the US president, such as Scott's attack on the western Ohio villages at Washington's bidding, depends upon how much the actions of each has aligned itself with those illegal, often aggressive settlers and speculators. Big Cat leaves little doubt how he understands the source of the ambiguities of conquest when he concludes,

if you will lengthen your patience, and manifest your power in withdrawing the Big knifes from the forts which stands on our land - then repeat your Message of peace to us. Then we will arise immediately, and exert ourselves to promote peace. Then we can assure the back nations that you have a power to govern the hostile Big knifes, and that you mean to have peace. Then the back nations will never regard the voice of these hostile Nations here. Then the war party will be speechless. ${ }^{67}$

Aupaumut makes clear he understands the problem of lawless Big Knifes who cross the Ohio River, the agreed upon boundary, when he summarizes, 'If the United States could govern [the Big Knifes, its own lawless citizens], then the peace could stand sure.' Aupaumut's narrative offers Indian and non-Indian publics access to the pointed question Big Cat asks. Does the US government have the power and the will to govern all the Big Knifes? In volunteering for this diplomatic mission, Aupaumut gave Washington and the US Congress the opportunity to say, yes, the new nation would curb race-baiting, reject the externalization of Indian lives and cultures as a subsidy for white unilateral acquisition of land and wealth, and separate the new republic from the empire it had defeated. In recording this intervention, Aupaumut enables us to witness a moment when this question was explicitly asked and peace was possible. That said, having fought against and alongside Americans, Aupaumut could have had no illusions about the violent path

\footnotetext{
${ }^{66}$ Ibid., 121.

${ }^{67}$ Ibid., 125.
} 
dependency the new nation already practised. Aupaumut returned home late in 1792 distressed by the grief expressed by friends and associates in Ohio Country. Seeing Aupaumut after his return east, a white US official in New York reported to Pickering that Aupaumut had succumbed to drink and despair. ${ }^{68}$

In the summer of 1793, Aupaumut was returning to The Glaize, nonetheless, with those three (white) US negotiators who were convinced a peace settlement was still possible because now they proposed to allow land speculators and settlers to buy Indian lands. But when he left the three Americans at Lake Erie and proceeded west alone to prepare the way, he found Indian war parties had formed, had taken charge and refused to meet with the US representatives until settlers and forts were removed from Ohio Country and the boundary was restored at the Ohio River. When the three commissioners heard this news, they went back east. Angry, Pickering wrote Aupaumut remembering he had said he was a friend of people of his own colour. ${ }^{69}$ Pickering seems not to have understood the sincere friendship to the USA Aupaumut pledged as commensurate with the peace Aupaumut sought.

\section{The unravelling of Aupaumut's intervention and the paving of the imperial path}

By 1826, the publication date of the English, text-only version of Aupaumut's book, the critical moment for Big Cat's crucial question had passed, and Aupaumut's English words had been excerpted from the full cross-cultural making of his book. In 1794, the US military pushed Aupaumut and diplomacy aside. General Anthony Wayne's defeat of the Indian Confederation at the Battle of Fallen Timbers on the Maumee River and subsequent destruction of established Indian villages along the river precipitated the 1795 Treaty of Greenville that invited settlers to inhabit Ohio Country to the Tuscarawas River and south of its confluence with the Muskingum.

Surveyor, speculator, mill owner, businessman and practitioner of white improvement, Bezaleel Wells first laid out and settled the town of Canton in 1805. As one made the 60-mile ride on the bridle path from the town of Steubenville on the Ohio River that he had established in 1797, the fork in the Nimishillen Creek was the first break in the wooded wilderness. It was unusual to choose a site not on a navigable lake or river, but the fork in the creek sat on an extended plain that did not necessitate clearing trees to build yet was proximate to timber. As a senator and composer of the constitution in Ohio, established as a state in 1803, Wells had insider knowledge in 1805 that a new county would soon be formed out of the large Columbiana County in north-eastern Ohio. His knowledge was consistent with the 'internal improvement' manifesting itself throughout the new nation: that is, despite (white) Americans' diverse visions of their future, improvement meant, first, physical structures such as roads, canals, schools and technological innovations and soon came to mean only 'public works for improved transportation'. ${ }^{70}$ The fork of the Nimishillen Creek sat in the middle of the new

\footnotetext{
${ }^{68}$ Taylor, 'Captain Hendrick Aupaumut: the dilemma of an intercultural broker', 447-8.

${ }^{69}$ Ibid., 449.

${ }^{70}$ J.L. Larson, Internal Improvement: National Public Works and the Promise of Popular Government in the Early United States (Chapel Hill, 2001), 15.
} 
county and would be a likely prospect for its county seat. An east-west road was planned from New Lisbon to the east across the Tuscarawas River to the west. Stark County historians write of early Cantonian villagers skittish about possible Indian attack but none occurred. Some isolated Wyandot, Ottawa and Senecas (Mingoes) were still 'roaming the forest' in what became Stark County, but most had been forced west. ${ }^{71}$

If, as Banner argues, the early US leadership wanted to see themselves as men of republican ethics and legitimate business contracts and not as agents of conquest a self-image not unlike their British predecessors - then the only way to do so and gain virtually all the land was to externalize much activity - fraud, violence, dissembling - that explicitly attended conquest. They would facilitate the actions of Big Knifes and minimize identification with them. Contracts would be silent on these activities or the prejudice of the markets, courts would reconstruct economic and legal history to accommodate the settler movement - often reimagining land speculators as settlers - and the national narrative and non-Indian literature would tell these stories. The major arterial in Toledo, Ohio, and a host of commemorative sites bear Anthony Wayne's name. The site of The Glaize and Vincennes negotiations - the very rivers themselves - and the names of those in attendance who sought peace are now lost in vast cornfields like those once planted and managed by the women of the prosperous western Indians.

'Never having seen an Indian before', the settlers of Stark County watched with curiosity, in the autumn of 1837, as the Ottawa on flatboats floating on the canal headed toward the Ohio River and out of Ohio Country. Already in the 1830s, the Ottawa would find in Cincinnati the largest pork-processing, disassembly line in North America, the result of replacing fields, orchards and fur-bearing animals in a swamp, with domestic animals at scale, a drained swamp and an ability now to exploit the riverine transportation the Miami knew so well. ${ }^{72}$ By 1881, as descendants of the Canton settlers wrote their history and as the city survived competition from the neighbouring new city of Massillon on the Ohio Canal, they would celebrate the industry built up along the Nimishillen Creek and the Tuscarawas River, externalizing then the waste of industry. Conquest by another name.

In the practices of imperial city-building there were, there are, moments for actors and writers to intervene, evocatively narrate the journey and ask who will name this conquest and govern its actions. On smaller scales, these moments are many; on a large scale, moments such as that Aupaumut addressed are more rare. Ann Hyde pursues a large-scale alternative to imperial practices when she writes of mixed race Indian-Euro-American family dynasties, engaged in the fur trade out of St Louis, Michilimackinac, Sante Fe and the Pacific Coast, promoting shared prosperity west of the Mississippi between 1800 and 1860 before a 'tangled process of conquest...eroded the web of relationship and families... [replacing them with] new racial ideologies and economic imperatives [that] had grave consequences for everyone concerned' ${ }^{73}$ European demand for furs and cross-racial

\footnotetext{
${ }^{71}$ G.W. Knepper, Ohio and Its People (Kent, OH, 2003), 77-80; E.T. Heald, The Stark County Story: Cities, Towns and Villages of Stark County, Ohio (Canton, OH, 1949), 1-2, 265.

${ }^{72}$ W. Cronon, Nature's Metropolis: Chicago and the Great West (New York, 1991), 228.

${ }^{73}$ A. Hyde, Empires, Nations, and Families (Lincoln, NB, 2011), 23.
} 
marriages enabled prosperity and power for some, but it is difficult to see racial ideologies, economic greed and imperial desires being held at bay even in the sites in question through the years 1800-60. James Daschuk writes of the devastation visited upon Indian villages on the Great Plains, including some prosperous ones, by disease and alcohol brought from travelling fur traders in the north and horse traders in the south as early as the seventeenth century and in continued activity throughout the eighteenth century. Weakened, these villages were yet more vulnerable to the agricultural pressure from the Little Ice Age and the global winter caused by volcanic eruption, both bringing starvation in the early nineteenth century. The toll on fur-bearing animals and their habitats should be mentioned as well. ${ }^{74}$ Also, as early as 1846 , William Wells Brown was publishing the narrative of his life as an enslaved person, sold to a man in St Louis as a boy and hired out to work on riverboats that transported enslaved Africans and their descendants in the internal slave trade once the international trade in slaves was outlawed early in the nineteenth century. ${ }^{75}$ Walter Johnson finds at the heart of American history a St Louis more aligned with Brown's experience than that of Hyde's fur-trading families. ${ }^{76}$ Whatever the chances for success in an intervention for peace, participation in improvement and shared power, Big Cat's question remains pertinent, neighbourhood by neighbourhood, nation by nation. Who will name this conquest and govern its actions?

The 1792 balance of power in Ohio Country and opportunity for some lawful sharing of the land and its resources having succumbed to US support of the Big Knifes, Aupaumut continued to petition for the welfare of his Mahican people in particular. By 1808, he was addressing Thomas Jefferson with the traditional 'Father' and pleading with him to corroborate the legality of the Mahican claims. 'Cast an eye of pity on us', he writes. ${ }^{77}$ With an eye cast across the wide Missouri, Jefferson, in his fatherly response, resurrects the old saw of John Locke, ventured more than a century earlier, that Indians, that is to say men, do not practise agriculture and therefore do not prosper on the land (and do not deserve it). If only your young men could be taught to love agriculture, Jefferson writes, you could 'live in peace and cultivate the earth' like the settlers who are multiplying like 'flocks of pidgeons'. Your poverty and starvation are your own fault. Because I am ever your friend, says Jefferson, I will sign over to you land on the White River near your friends the Miamis. ${ }^{78}$ Aupaumut subsequently led his community to this piece of Ohio Country in 1817 and 1818 only to have federal officials in 1818 deny them the promised tract on the White River, violating Jefferson's commitment by claiming the Miami had already signed over the land to the USA. ${ }^{79}$

\footnotetext{
${ }^{74}$ J. Daschuk, Clearing the Plains: Disease, Politics of Starvation, and the Loss of Aboriginal Life (Regina, SK, 2013).

${ }^{75}$ W.W. Brown, Narrative of William W. Brown, a Fugitive Slave. Written by Himself (Boston, MA, 1847).

${ }^{76}$ W. Johnson, The Broken Heart of America: St. Louis and the Violent History of the United States (New York, 2020).

${ }^{77}$ National Archives of the United States, letter from Hendrick Aupaumut to Thomas Jefferson, 12 Dec. 1808, https://founders.archives.gov/documents/Jefferson/99-01-02-9295, accessed 24 Jun. 2020.

${ }^{78}$ National Archives of the United States, letter from Thomas Jefferson to Hendrick Aupaumut, 21 Dec. 1808, https://founders.archives.gov/documents/Jefferson/99-01-02-9358, accessed 24 Jun. 2020.

${ }^{79}$ Taylor, 'Captain Hendrick Aupaumut: the dilemma of an intercultural broker', 452.
} 
Descendants of Ohio Indians continued, continue, to fight for their collective lives and cultures after most left the territory of Ohio. This history of city-building and their removal from Ohio Country is not the end of their story. It is, however, a reminder of imperialism's presence at the beginning of the story of US cities. Out of its anarchy, it established patterns of what Williams calls 'improvement' and most Americans would now call 'economic development'. Among these patterns are ones not often discussed by city staff or in city council meetings now: the displacement and usurpation of established non-white settlements, the evacuation of women's social and economic success from the historical record (especially the success of women of colour), the use of military and political force to uphold constructed racial loyalty over the Anglo-Americans' own laws and, as Cronon concludes, the profound 'alienat[ion of] the products of the land as much as the products of human labor'. ${ }^{80}$ To this list, we could add the ubiquitous commemoration of war and its male actors - whether winners or losers - in the cities and the country and the near absence of commemoration of peace and peacemakers. Notwithstanding the diverse social, economic, political and environmental positions and actions of Cantonian descendants, details of the imperial history of this and all US cities lie before us - largely unheeded.

\section{The prospect of breaking imperial patterns through the generative energy of the past}

In a book called The Moral Imagination, peace negotiator and scholar John Paul Lederach describes his learning, from indigenous people in many sites throughout the world, the lesson that the past lies before us and the future behind. The past ahead of us is what we know, or should know, and can see. We walk, by necessity, backwards toward a future we cannot see and do not know. This lesson delivered by these teachers (rather than European philosophers) became a key to his writing about and facilitating peace negotiations whether in the Philippines or Northern Ireland or East and West Africa or Colombia or the Balkans. He offers the art of imagining and expressing the past as an alternative to the

pragmatic politics and quick solutions, which occupy so much space in the symptomatic discussions of immediate problems. The art of imagining the past will, without fear of entering unpredictable territory or fear of recrimination, develop a curiosity about the patterns, the cycles, and the story that repeats itself. Knowing that the past is a generative energy, it will seek to find and engage where the narrative has been broken. The moral imagination will see itself in relationship with this energy. ${ }^{81}$

Through his multi-modal narrative creation, Aupaumut displayed the generative energy of the past and clarified the choices before participants in negotiations at a moment in a place when a balance of power could enable a more equitable sharing of resources and dignity. He (and the women at Vincennes) did not succeed in breaking the imperial patterns of city-building and country resource exploitation

\footnotetext{
${ }^{80}$ Cronon, Changes in the Land, 170.

${ }^{81}$ J.P. Lederach, The Moral Imagination: The Art and Soul of Building Peace (New York, 2005), 148.
} 
in place as a new nation hurried to establish itself and build its wealth for some while exacting a high cost from others. But they recognized and seized a moment in a place when and where an intervention was possible.

Stuck in traffic on a street lined with franchise businesses come today gone tomorrow, the past lies before us. The child living now with the bulldozers at her heel evokes the patterns and cycles of violent removal at the beginnings of her metropolitan area but also, as it turns out, evokes a possible break in this narrative that too is a part of her past. The energy generated by Aupaumut's actions and the voices of the historical actors recorded in his book could propel a person say an urban planner, an urban government - beyond quick solutions, well-worn paths, to a kind of improvement endowed with moral imagination always in relationship to an expanding knowledge of the past. This is not naïve kindness.

Cite this article: Eckstein B (2023). Empires' city-building and the 1792 intervention of Aupaumut's book. 